\title{
SECTORAL EMPLOYMENT DIVERSIFICATION IN RURAL AREAS ACROSS POLISH SUBREGIONS
}

\author{
Nina Drejerska ${ }^{1}$, Mariola Chrzanowska \\ ${ }^{1}$ Katedra Polityki Europejskiej i Marketingu \\ Szkoły Głównej Gospodarstwa Wiejskiego w Warszawie \\ Kierownik Katedry: dr hab. Joanna Szwacka-Mokrzycka, prof. SGGW, \\ ${ }^{2}$ Katedra Ekonometrii i Statystyki Szkoły Głównej Gospodarstwa Wiejskiego w Warszawie \\ Kierownik Katedry: dr Andrzej Karpio
}

\begin{abstract}
Key words: employment, rural areas, spatial autocorrelation, NUTS3
Stowa kluczowe: zatrudnienie, obszary wiejskie, przestrzenna autokorelacja, NUTS3
\end{abstract}

\begin{abstract}
A b s t r a c t. Agriculture, forestry and fishing have been still a very important part of the labour market. However, the situation is diversified across Polish subregions. The objective of the study is to investigate sectoral employment diversification in rural areas across Polish subregions (NUTS3). In order to do it, data on the subregional employment structure provided by the Central Statistical Office of Poland was used for computation of spatial autocorrelation described by Moran's statistics. Results of this analysis display for example a cluster of subregions in south-east Poland, where employment in agriculture, forestry and fishing is a significant trend of predominantly rural subregions.
\end{abstract}

\section{INTRODUCTION}

France, Germany, Poland, Italy and Romania had the largest populations in predominantly rural regions. These five Member States were home to $60.5 \%$ of the EU-27's population found to be living in predominantly rural regions [Eurostat 2015]. Rural inhabitants in Poland have been traditionally connected with agriculture. Although it is raised that this situation has been experiencing profound changes over recent decades - Neil Ward and David Brown [2009] indicate that employment in agriculture and other land-based industries has shrunk, so the economic fortunes of rural areas have come to depend upon a much wider range of drivers than the economic fortunes of the primary sector. According to the data of the Central Statistical Office of Poland, on average 38\% of inhabitants of predominantly rural areas were employed in agriculture, forestry and fishing in 2013. It illustrates the fact that these sectors have been still a very important part of the labour market. However, the situation is diversified across Polish regions. Proportion of inhabitants of predominantly rural regions employed in agriculture, forestry and fishing varied from $8 \%$ in the Silesia region to $45 \%$ in the Lubelskie region. Moreover, predominantly rural areas are also a place of significant relative decrease in employment in the primary sector and increase in the tertiary sector [Drejerska 2014]. This general trend is also diversified 
regionally as result of many research investigations display regional differences of rural development referring a significant aspects of life, including size and productivity of the farms, demographic structure and also selected aspects of labour market [Rosner 2011, Poczta 2012, Szymańska et al. 2009].

A review of the state of the art displays that the diversification of the local labour market in the rural areas is a subject of many analyses. Due to the fact that regional development is multidimensional phenomena, a lot of authors use multidimensional comparative analysis for these kinds of studies. For example, Natalia Bartkowiak-Bakun [2017] comprises rural areas in Poland in the western borderland, i.e. West Pomeranian, Lubuskie and Lower Silesian regions with the George Frederick Jenks method applied for grouping entities into classes characterised by similar levels of development [Jenks 1967]. Jerzy Bański and Marcin Mazur [2016] proposed the methodological procedure of the new typology concentrating on three aspects: development dynamics, economic structure and transport-wise accessibility. This approach generated the synthetic image of the spatial differentiation and the state of rural areas development.

\section{RESEARCH METHODS}

The objective of the study is to investigate sectoral employment diversification in rural areas across Polish subregions (NUTS3). Detailed aims assume to examine if there are some clusters of subregions of similar sectoral employment patterns and then to verify if such clusters of subregions cover administrative boundaries of regions (voivodships in Poland). This approach assuming analysis on the level of subregions (NUTS3) is something between a regional approach provided for example by Katarzyna Łukiewska and Katarzyna Chrobocińska [2015] for spatial differentiation of production potential of agriculture in Poland or Anna Rzeszutko [2106] for regional structural analysis of farms in Poland and Monika Stanny [2010], who investigated spatial diversification of the balance on the labour market in rural areas in Poland on the local level - 2,171 rural communes and the rural areas of the urban-rural communes according to the administrative division (according to the data of the National Census from the year 2002).

For the purposes of this study, a new European Union (EU) typology of: predominantly rural, intermediate, and predominantly urban regions was applied [Eurostat 2012]. To summarize this methodology, it can be described in three steps (Eurostat, Urban-rural typology):

1. Creation of clusters of urban grid cells with a minimum population density of 300 inhabitants per $\mathrm{km}^{2}$ and a minimum population of 5000 . All the cells outside these urban clusters are considered as rural.

2. Grouping NUTS 3 regions of less than $500 \mathrm{~km}^{2}$ with one or more of its neighbours solely for classification purposes, i.e. all the NUTS 3 regions in a grouping are classified in the same way.

3. Classification of NUTS 3 regions based on the share of population in rural grid cells:

- more than $50 \%$ of the total population in rural grid cells = predominantly rural,

- between $20 \%$ and $50 \%$ in rural grid cells = intermediate,

- less than $20 \%=$ predominantly urban.

In Poland, according to this methodology there were (fig. 1) 16 predominantly urban regions, 22 intermediate regions and 28 predominantly rural regions in 2012. 


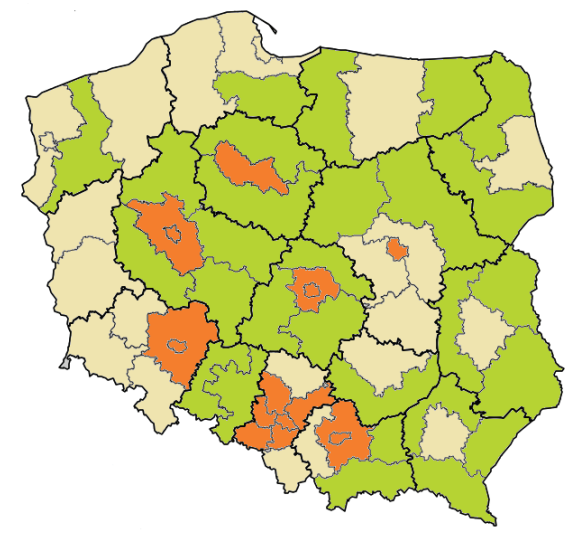

$\square$ Predominantly urban regions

$\square$ Intermediate regions

$\square$ Predominantly rural regions

Figure 1. Rural-urban typology of the Polish NUTS 3 regions

Source: Eurostat, Urban-rural typology, http://ec.europa.eu/eurostat/statistics-explained/ index.php/Urban-rural_typology (accessed on 31/08/2015).

The basic research question is to find if Polish subregions (NUTS 3) can be divided into clusters of a similar sectoral employment structure. In order to provide such analysis we will use principles of spatial autocorrelation. Analysis of the phenomenon of spatial autocorrelation is based on the values attributed to spatial objects. Spatial autocorrelation means that the objects close geographically are more similar to each other than those far. This phenomenon causes usually the formation of spatial clusters of similar values. Research of spatial autocorrelation of employment is carried out using the Moran's statistics. This measure is discussed for example by Oliver Schabenberger and Carol Anne Goteway [2005] and was used for the employment analysis for example by Sanna-Mari Ahtonen [2003], Annekatrin Niebuhr [2003] or Nina Drejerska and Mariola Chrzanowska [2014]. For example, M. Chrzanowska [2016] also provided analysis of agricultural land prices by regions in Poland using Moran's statistics.

The value of Moran's statistic generally falls into the interval $[-1,1]$ and three different situations may occur:

- $\quad I=0-$ no autocorrelation

- $\quad I<0$ - negative autocorrelation (objects that are located next to each other at a specified distance have different values

- $\quad I>0$ - positive autocorrelation (objects located next to each other, at a specified distance, have similar values).

The Global Moran's statistic is described by the formula (1):

$$
I=\frac{n}{W} \frac{\sum_{i=1}^{n} \sum_{j=1}^{n} w_{i j}\left(x_{i}-\bar{x}\right)\left(x_{j}-\bar{x}\right)}{\sum_{i=1}^{n}\left(x_{i}-\bar{x}\right)^{2}}
$$

$w_{i j}$ - weight of the connections between units $i$ and $j$ (1st order matrix standardised according to rows), $x_{i} x_{j}$-value of the variables in spatial units $i$ and $j$ ( $1^{\text {st }}$ order matrix standardised according to rows), $\bar{x}$ - arithmetic mean value of the analysed variable for all spatial units.

The global Moran described only a certain pattern observed in the whole area. To investigate the changes in the individual spatial units, other measures (local ones) should be used. These indicators are determined separately for each region. This allowed accurate 
access to the diversity of the studied phenomenon. In other words, based on local statistics, we can judge whether the tested area is adjacent to areas of low or high values. Such an analysis allows to detect clusters of areas of high (or low) value of the tested variable, and also identify unusual areas (values of which significantly differ from their neighbours). The most commonly used measure is the local Moran's statistic (for more details see: [Anselin 1995]). This characteristic is used to examine how the value of one region is formed in comparison with neighbouring regions, as compared to a random distribution of values in the tested area. The local Moran's statistic is expressed by the formula:

$$
I_{i}=\frac{\left(x_{i}-\bar{x}\right)^{2} \sum_{i=1}^{n} w_{i j}\left(x_{j}-\bar{x}\right)}{\frac{\sum_{i=1}^{n}\left(x_{i}-\bar{x}\right)^{2}}{n}}
$$

Description as previously.

Data used in the study comes from the Local Data Bank provided by the Central Statistical Office of Poland and concerns the year 2012. We analysed proportions of employed persons (males and females) employed in:

- agriculture, forestry and fishing,

- industry and construction,

- trade; repair of motor vehicles; transportation and storage; accommodation and catering; information and communication;

- financial and insurance activities; real estate activities;

- other services.

\section{RESULTS AND DISCUSSION}

In order to determine the impact of employment in neighbouring subregions for a situation in a specific subregion, global Moran's statistic was calculated (tab. 1.). The significance of the obtained values can be estimated basis on $p$-value. Results in Table 1 prove that all statistics are statistically significant. Therefore, it can be concluded that there is a positive (moderate or weak) spatial autocorrelation in the employment structure. It means that there exist clusters of subregions of similar proportions of employment in particular sectors.

Local Moran I values are presented in Figures 2-10, which illustrate clusters of subregions (NUTS 3) similar in case of proportions of persons (also males and females) employed in particular sectors. Regions marked with red represent clusters of similar regions in case of high proportion of employment in particular sector whereas those marked with blue represent clusters of similar regions in case of low proportion of employment in particular sector.

For employment in financial and insurance activities, real estate activities as well as other services, there were not clear results in case of spatial patterns, especially for total and male employment. A cluster of subregions similar in case of total employment in agriculture, forestry and fishing includes all predominantly rural regions of the following regions: malopolskie, podkarpackie, świętokrzyskie, lubelskie as well as parts of mazowieckie and podlaskie (fig 2, 3, 4). Exactly the same pattern was find in the case of female employment in these sec- 
Table 1. Moran's global statistic for subregions (NUTS3)

\begin{tabular}{lcc}
\hline Sectors of employment & $\begin{array}{c}\text { Global Moran's } \\
\text { Statistics I }\end{array}$ & p-value \\
\hline Total employment in agriculture, forestry and fishing & 0.467 & $<0.00$ \\
Male employment in agriculture, forestry and fishing & 0.445 & $<0.00$ \\
Female employment in agriculture, forestry and fishing & 0.497 & $<0.00$ \\
Total employment in industry and construction & 0.500 & $<0.00$ \\
Male employment in industry and construction & 0.549 & $<0.00$ \\
Female employment in industry and construction & 0.338 & $<0.00$ \\
$\begin{array}{l}\text { Total employment in trade; repair of motor vehicles; } \\
\text { transportation and storage; accommodation and catering; }\end{array}$ & 0.284 & $<0.00$ \\
$\begin{array}{l}\text { information and communication } \\
\text { Male employment in trade; repair of motor vehicles; } \\
\text { transportation and storage; accommodation and catering; }\end{array}$ & & \\
information and communication & 0.224 & $<0.00$ \\
$\begin{array}{l}\text { Female employment in trade; repair of motor vehicles; } \\
\text { transportation and storage; accommodation and catering; }\end{array}$ & & \\
information and communication & 0.382 & $<0.00$ \\
\hline
\end{tabular}

Source: own calculations.

tors and very similar spatial one in case of male employment. What is a logical consequence of such accumulation of employment in the primary sector in this part of Poland, the results displayed on figures 5-10 prove low proportions of employment in industry and construction as well as trade; repair of motor vehicles; transportation and storage; accommodation and catering; information and communication. A similar result of spatial analyses of sectoral employment across the predominantly rural regions in Poland was presented by N. Drejerska [2015] - agriculture, forestry and fishing were indicated as a very important

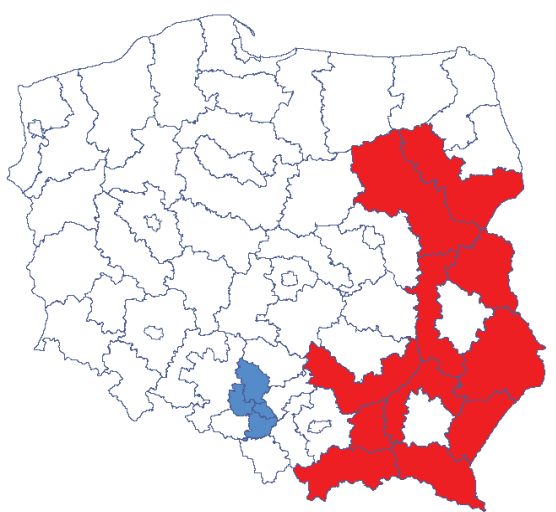

Figure 2. Clusters of subregions similar in case of total employment in agriculture, forestry and fishing Source: own elaboration.

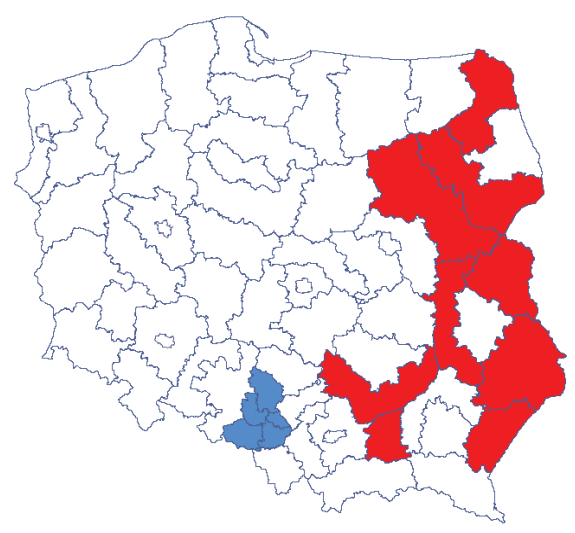

Figure 3. Clusters of subregions similar in case of rural male employment in agriculture, forestry and fishing Source: own elaboration. 
sector of employment in the south-eastern part of Poland whereas the second and third sectors were more popular in the employment structure of the north-western part of Poland. However, it should be also stressed that this group of subregions goes beyond administrative regional boundaries, which proves an existence of a bigger functional region of high important of agriculture in the economy.

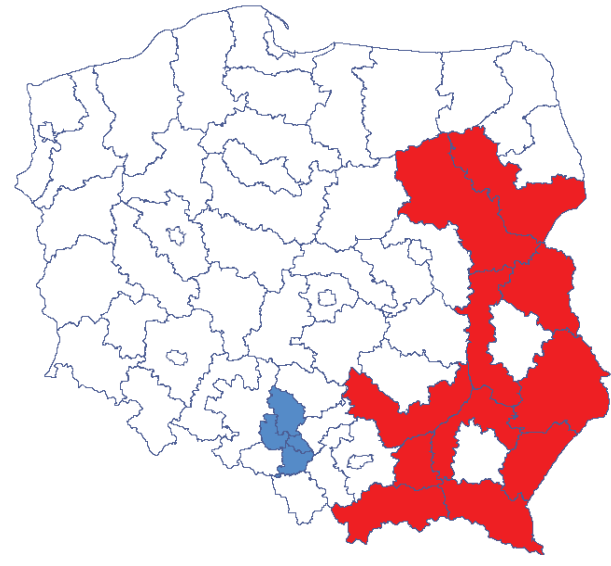

Figure 4. Clusters of subregions similar in case of rural female employment in agriculture, forestry and fishing

Source: own elaboration.

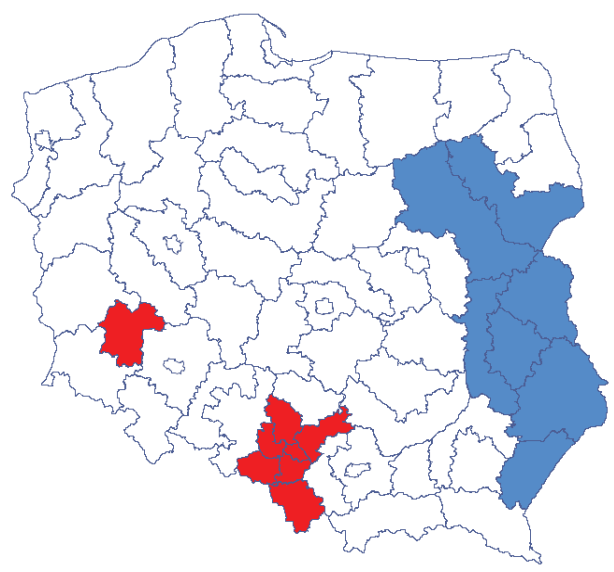

Figure 6. Clusters of subregions similar in case of rural male employment in industry and construction Source: own elaboration.

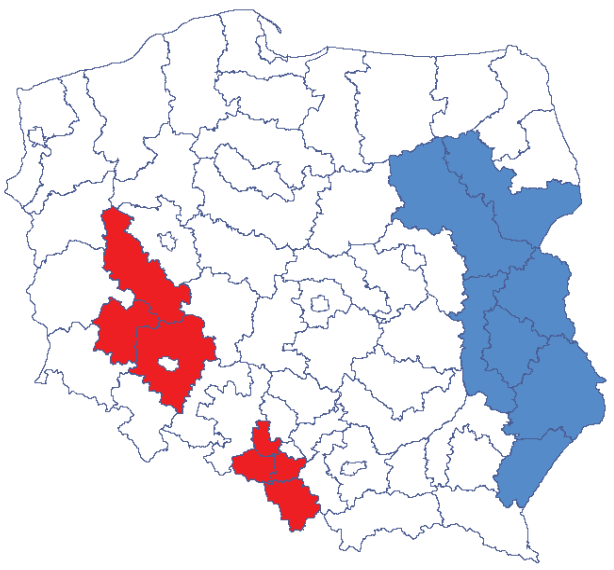

Figure 5. Clusters of subregions similar in case of total employment in industry and construction Source: own elaboration.

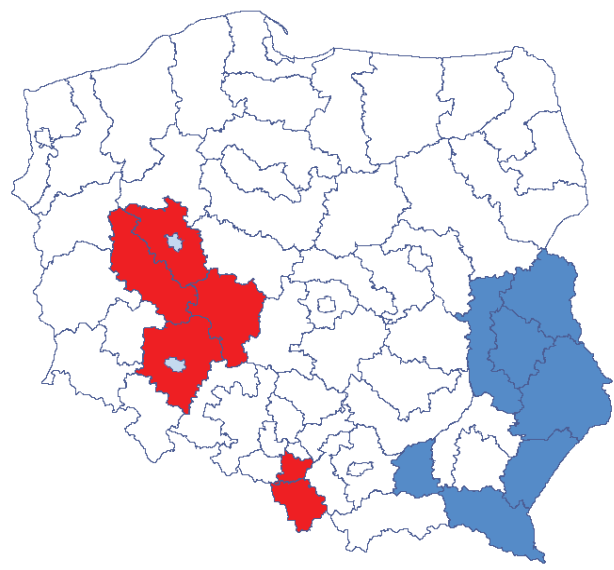

Figure 7. Clusters of subregions similar in case of rural female employment in industry and construction Source: own elaboration. 


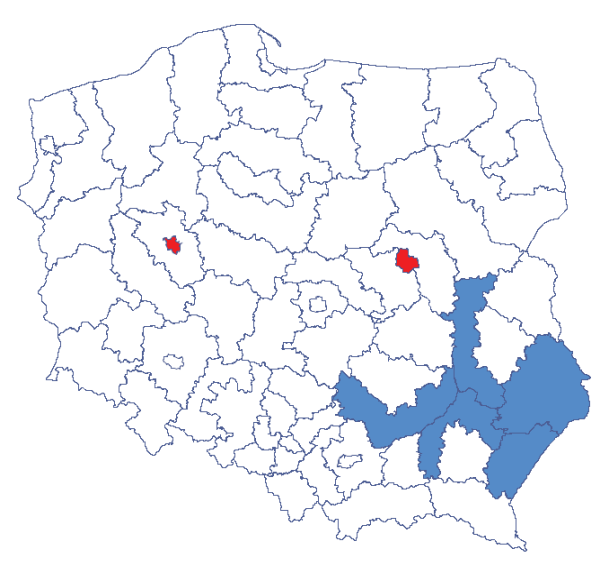

Figure 8. Clusters of subregions similar in case of total employment in trade; repair of motor vehicles; transportation and storage; accommodation and catering; information and communication Source: own elaboration.

Figure 10. Clusters of subregions similar in case of rural female employment in trade; repair of motor vehicles; transportation and storage; accommodation and catering; information and communication Source: own elaboration.

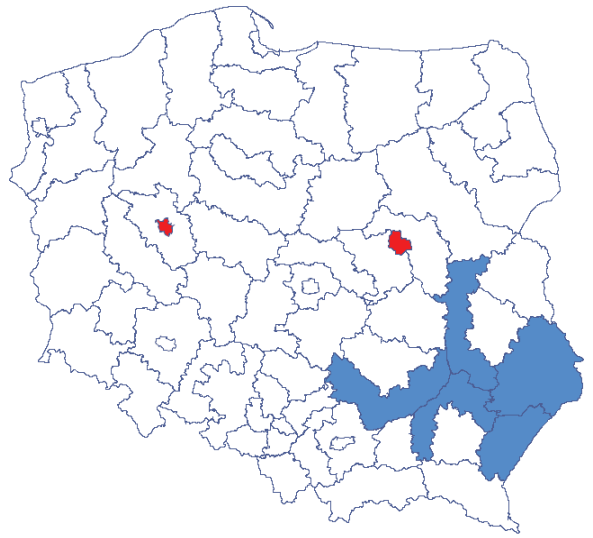

Figure 9. Clusters of subregions similar in case of rural male employment in trade; repair of motor vehicles; transportation and storage; accommodation and catering; information and communication Source: own elaboration.

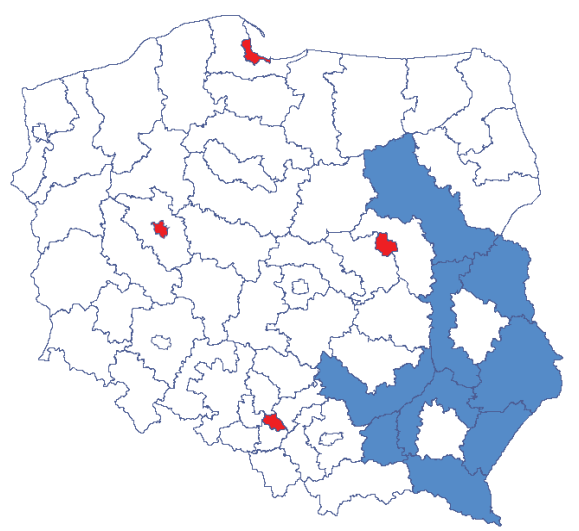

\section{CONCLUSIONS}

Undoubtedly, there is a cluster of subregions in south-east Poland, where employment in agriculture, forestry and fishing is a significant trend of predominantly rural areas. This cluster exceeds administrative regional boundaries (of voivodships), which proves an existence of a functional region of high importance of agriculture in the economy. To the contrary, such trends cannot be noticed in the west part of Poland. As a logical consequence of such accumulation of employment in the primary sector in south-east Poland, there were identified low proportions of employment in industry and construction as well as trade, repair of motor vehicles, transportation and storage, accommodation and catering, information and communication. Identification of such employment diversification in rural areas can contribute for example to planning education facilities or instruments of labour market. 


\section{REFERENCES}

Ahtonen Sanna-Mari, 2003: Spatial autocorrelation in employment-output relation https://www.jyu. fi/ersa2003/cdrom/papers/209.pdf

Anselin Luc, 1995: Local Indicators of Spatial Association - LISA, "Geographical Analysis", 27(2), p. 93-115.

Bański Jerzy, Marcin Mazur, 2016: Classification of rural areas in Poland as an instrument of territorial policy, "Land Use Policy", 54, p. 1-17.

Bartkowiak-Bakun Natalia, 2017: The diversity of socioeconomic development of rural areas in Poland in The Western Borderland and the problem of post-state farm localities, "Oeconomia Copernicana", 8(3), p. 417-431.

Chrzanowska Mariola, 2016: Spatial analysis of agricultural land prices by regions in Poland Economic Science for rural development, Proceedings of International Scientific Conference, Jelgava, p. 22-29.

Drejerska Nina, 2014: Obszary przeważająco wiejskie w Polsce - perspektywa rynku pracy, [in:] Rolnictwo, gospodarka żywnościowa, obszary wiejskie - 10 lat w Unii Europejskiej, ed. Nina Drejerska, Publishing House SGGW, Warsaw, p. 57-68.

Drejerska Nina, 2015: Spatial patterns on the labour market on rural areas in Poland, Proceedings of the International Scientific Conference Rural Development 2015, $5 \mathrm{~s}$.

Drejerska Nina, Mariola Chrzanowska, 2014: Commuting in the Warsaw suburban area from a spatial perspective - an example of empirical research, "Acta Universitatis Lodziensis. Folia Oeconomica", vol. 6, no 309, p. 87-96.

Eurostat, 2012: Eurostat regional yearbook 2012, Publications Office of the European Union, Luxembourg, p. 195-200.

Eurostat, 2015: Agriculture - rural development statistics http://ec.europa.eu/eurostat/statisticsexplained/index.php/Agriculture__rural_development_statistics, access 12.12.2017.

Eurostat, Urban-rural typology, http://ec.europa.eu/eurostat/statistics-explained/index.php/Urbanrural typology (access 31/08/2015)

Jenks George Frederick, 1967: The data model concept in statistical mapping, "International Yearbook of Cartography", 7, p. 186-190.

Łukiewska Katarzyna, Katarzyna Chrobocińska, 2015: Przestrzenne zróżnicowanie potencjału produkcyjnego rolnictwa w Polsce, ,Roczniki Naukowe Ekonomii Rolnictwa i Rozwoju Obszarów Wiejskich", vol. 102, no. 3, p. 56-65.

Niebuhr Annekatrin, 2003: Spatial Interaction and Regional Unemployment in Europe, "European Journal of Spatial Development", 5, p. 1-26.

Poczta Walenty, 2012: Przemiany w rolnictwie ze szczególny uwzględnieniem przemian strukturalnych, [in:] Polska wieś 2012. Raport o stanie wsi, eds. Jerzy Wilkin, Iwona Nurzyńska, FDPA, Warsaw p. 65-99.

Rosner Andrzej, 2011: Zróżnicowanie przestrzenne obszarów wiejskich [in:] Rozwój obszarów wiejskich w Polsce. Diagnozy, strategie, koncepcje polityki, Nurzyńska Iwona, Drygas Mirosław (eds.), IRWiR PAN, Warsaw, s. 155-174.

Rzeszutko Anna, 2016: Zmiany struktury ekonomicznej gospodarstw rolnych w Polsce w ujęciu regionalnej analizy strukturalnej, ,Roczniki Naukowe Ekonomii Rolnictwa i Rozwoju Obszarów Wiejskich", vol. 103, no 4, p. 32-47.

Schabenberger Oliver, Carol Anne Gateway, 2005: Statistical method for Spatial Data Analysis, Chapman\&Hall, London, p. 23-25.

Stanny Monika, 2010: Spatial Diversification of the balance on the labour market in rural areas in Poland, "Bulletin of Geography, Socio-economic. Series 14", Toruń: Nicolaus Copernicus University Press, p.103-111.

Szymańska Daniela, Biegańska Jadwiga, Gil Anna, 2009: Rural areas in Poland in the context of changes in population age structure in 1996, 2001 and 2006, "Bulletin of Geography, Socio-economic. Series 12", Torun: Nicolaus Copernicus University Press, p. 91-107.

Ward Neil, David L. Brown, 2009: Placing the Rural in Regional Development, "Regional Studies", 43, p. 10. 
Nina Drejerska, Mariola Chrzanowska

\section{SEKTOROWE ZRÓŻNICOWANIE ZATRUDNIENIA NA OBSZARACH WIEJSKICH W POLSKICH PODREGIONACH}

\section{Synopsis}

Rolnictwo, leśnictwo i rybolówstwo sq nadal ważnymi sektorami zatrudnienia aczkolwiek sytuacja w tym zakresie jest $w$ Polsce zróżnicowana w poszczególnych podregionach. Celem opracowania jest identyfikacja sektorowej struktury zatrudnienia wedlug podregionów (NUTS3). Dane uzyskane z Gtównego Urzędu Statystycznego postużyty do sprawdzenia istnienia autokorelacji przestrzennej opisanej statystykami Morana. Uzyskane rezultaty pozwolity na identyfikację klastra subregionów w poludniowo-wschodniej części kraju, gdzie zatrudnienie w rolnictwie, leśnictwie i rybolówstwie jest ważna częśsią rynku pracy na obszarach przeważająco wiejskich.

Correspondence address:

Nina Drejerska, $\mathrm{PhD}$

Warsaw University of Life Sciences - SGGW

Department of European Policy and Marketing, Faculty of Economic Sciences 166 Nowoursynowska St., 02-787 Warsaw, Poland e-mail: nina_drejerska@sggw.pl

Mariola Chrzanowska, $\mathrm{PhD}$

Warsaw University of Life Sciences - SGGW

Department of Econometrics and Statistics, Faculty of Applied Informatics and Mathematics

159 Nowoursynowska St., 02-776 Warsaw, Poland e-mail: mariola_chrzanowska@sggw.pl 